\title{
Ghana and the World Music Boom
}

\author{
John Collins \\ School of Performing Arts, University of Ghana
}

From the 1950s to the early 1970s Ghana led the way in West Africa with its popular highlife and Afro-rock music and its viable recording and music production industry. However, things began to decline from the late 1970s due to a corrupt military government, followed by two coups, several years of night curfew and the imposition of massive import duties on musical instruments. Into the music vacuum came Ghanaian gospel-music (as the churches were not taxed) and hitech drum-box and synthesizer forms of local music (burgher highlife and hiplife) that did away with large expensive bands. By the mid-1980s the live commercial music and entertainment scene was almost at a stand-still, exactly at a time when there was a growing international interest in African music. However, the Ghanaian non-commercial gospel-music or computerized forms of music that appeared in the 1980s and 1990s were too hi-tech for the psychology of the World Music fans, who demanded "authentic" African sounds. Although Ghana was initially unable to benefit much from the early World Music boom, there have, however, been a number of important positive spin-offs from this international phenomenon.

Some of these directly benefit Ghanaian musicians. Today hundreds of foreign musicians, students and World Music fans are coming to study African performance at Ghana's universities or in the private drum and dance schools as well as beach resort and folkloric groups that have sprung up since the late 1980s. World Music has also encouraged a small number of local musicians to continue with the older forms of live performance of highlife instead of joining the hi-tech "canned" and "mimed" approach to musical performance and production. Additionally, there are nowadays hundreds of Ghanaian musicians in Europe, America and Australia, playing in World Music outfits or teaching African music at schools and colleges.

Another positive impact results from the substantial royalties that derive from Paul Simon using an old Ghanaian song in his album "Rhythm of the Saints". In 1991 these royalties were used to help establish the Ghanaian National Folklore Board 
of Trustees, which is making an inventory of Ghanaian folklore and monitoring its commercial use by foreigners.

The lucrative World Music industry has also led to the Ghanaian government reconsidering the role of popular entertainment, largely disregarded by the governments of the past twenty-five years. The Ministry of Tourism is also behind this move as over the last five years tourism has become the third largest foreign exchange earner for Ghana, with ten percent of tourist revenue being spent on entertainment. This move to elevate the entertainment sector has been further encouraged since June 2000 by the World Bank initiative to assist the music industries of six African countries, including Ghana. As a result, in 2004 the Ghanaian government reduced the massive import duties on musical instruments that have crippled the local live music industry for over twenty years. Furthermore, the entertainment industry is added to the current Ghana Poverty Reduction Strategy, and the Ghanaian Parliament is currently working on a new copyright bill to curb music piracy.

In this chapter I will explore these themes more deeply. For the background, I will first, however, give a short overview of the developments in and the early international flows of the Ghanaian music in the 1960s and 70s - the summary is based on my own experiences as an observer and musician in Ghana.

\section{African Popular Music in the 1960s and 70s}

In 1969, when I first began working as a musician in Ghana, highlife was the dominant commercial music style in the country, and although it had never become international it had, during the 1950s and 1960s, become popular in many African countries, particularly in Nigeria. Many of the youth were also interested in imported rock music and soul and the various "psychedelic" and "Afro" fashions that went with them. The fusion of these imported pop dance-music styles with local idioms (such as highlife and makossa) subsequently led to the emergence of Afro-fusion music in the early 1970s. There was the Afro-rock music of the London-based Ghanaian group, Osibisa that had a string of record hits in Europe from the early to mid1970s. Their successful Afro-rock resulted in a host of similar bands being set up in Africa, particularly in English speaking countries. ${ }^{1}$ Then there was the Afro-soul music of Segun Bucknor of Nigeria and also Manu Dibango of the Cameroons. The latter settled in France and had a big hit in 1972 in the USA with his "Soul Makossa" album in the early 1970s. At the same time Fela Anikulapo Kuti of Nigeria was

1 Ghana: Hedzolleh Sounds, Basa-Basa, the Bunzus, the Psychedelic/Magic Aliens, Cosmic Boombaya and Q Masters. Nigeria: Tee Mac, Joni Haastrup's Mono Mono, Ofo and the Black Company BLO, the Lijadu Sisters, Ofege and the Funkees. Sierra Leone: Super Combo and the Echoes. Kenya: Matoto and Makonde. South Africa: Harari and Juluka (Sipho Mabuse and Johnny Clegg). 
putting his Afro-beat sound together in Lagos, a music style that was quickly taken up by groups in neighbouring countries, such as Ghana (Big Beats and Sawaaba Sounds) and Benin (Polyrhythmic Orchestre).

This Afro-fusion music was taken abroad by African bands and artists who became resident in Europe and the United States, such as Osibisa, Boombaya and Super Combo in London, Manu Dibango in Paris, and Hedzolleh and Ofo and the Black Company in the United States. However, what really made this music popular outside of Africa, particularly in Europe in the early 1970s, was that it provided a dance-music to pop music fans at a time when Western rock music was moving away from providing music for dancing, to one of putting onstage stunning displays of virtuosity by rock "superstars" for passive, watching audiences. Soul music was not at that time so popular in Europe, disco and reggae had not yet fully surfaced, and so there was in Western Europe a temporary dance vacuum in the popular music scene, which Afro-fusion, and Osibisa's Afro-rock in particular, helped fill.

However, the drum-machine disco music of Kraftwerk and Donna Summer and others then became fashionable in Europe, followed by ska and later reggae dance-music. These came to fill the existing dance vacuum and Afro-fusion bands lost their popularity in Europe. Consequently, the most famous of the Afro-fusion bands, Osibisa, had to start touring in Asia and Australia. Conversely, in United States, except for Manu Dibango's Soul Makossa hit, Afro-fusion music did not really make an impact at all in the 1970s; the USA had its own soul and other black dance-music, and so never experienced the dance vacuum of the European type.

Therefore, African music almost became World Music in the 1970s, but because of the waxing of disco and reggae, it took another ten years for this to happen. Next I will look at the general reasons for the growing international interest in highlife, Afro-rock, Afro-beat, juju music, soukous, chimurenga, South African township music and other forms of "Afro-pop" since the early 1980s.

\section{Reasons for the International Breakthrough of Afro-Pop in the Early 1980s}

First: Afro-pop is a logical extension of the global emergence of the black dancemusic of the Americas and the Caribbean that began in the late $19^{\text {th }}$ century, from jazz, blues and the samba right up to today's reggae, rap and salsa. The gradual internationalization of the black popular music of the Americas ultimately paved the way for the popular music of Africa itself going global.

Secondly: Afro-pop is intrinsically global in its style. Unlike traditional ethnic African music that is usually located in a specific local culture, contemporary African 
popular music is a fusion of African, Western, black American, and in some cases Arabic and even Indian influences. It is therefore intrinsically an international idiom suitable for an international audience.

Thirdly: There has been a growing interest in African music by jazz and rock stars. From the 1960s modern jazz musicians, such as John Coltrane, Max Roach, Sun $\mathrm{Ra}$ and Randy Weston became interested in African music. The residency in the United States of Ghana's Kofi Ghanaba (then known as Guy Warren) and Nigeria's Babatunde Olutunji played an important role in this development, as these percussionists interacted with the jazz fraternity - in the case of Guy Warren, as early as the 1950s. ${ }^{2}$ From the 1970s, British and American rock stars also began visiting Africa; the drummer Ginger Baker ${ }^{3}$, Paul McCartney of the Beatles ${ }^{4}$, Sting and Stuart Coplan of the band Police, Mick Fleetwood and the rock composer Brian Eno. Paul Simon released his African influenced smash-hit "Graceland" album in 1986. Around that time the radio journalist Sean Barlow visited Ghana, and in 1987 he and George Collinet started up the Afro-Pop program of Public Radio, syndicated on thirty US radio stations. ${ }^{5}$ More recent visits to Africa by British pop musicians include those of Damon Alban of Buzz and Gorilla and of Jamie Cato and Duncan Bridgeman of Faithless and One Giant Leap. ${ }^{6}$ There is also today an enormous interest by American and European "techno-music" DJs and dance-fans in Fela Anikulapo-Kuti's Nigerian Afro-beat music, which they use to create their electronic dance-floor grooves.

Fourthly: Even though reggae dance music initially, in the early 1970s, took the wind out of Afro-rock and contributed to the delay in the internationalization of African popular music, in the 1980s, reggae instead helped to enhance the global interest in Afro-pop. Indeed, Jamaican reggae and rastafarianism acted as a stepping-stone to African music for many Western musicians. The back-to-Africa theme in rastafarianism and reggae has encouraged many West Indian and white reggae bands to turn to African music for inspiration. Some of these artists visited Africa; Jimmy Cliff ${ }^{7}$ visited Nigeria, Misty and Roots and Greg Isaacs visited Ghana,

2 Guy Warren worked with African American jazz musicians Thelonius Monk, Miles Davis, Max Roach and Billy Strayhorn and as a result in the 1950s began releasing a string of seminal Afro-Jazz record albums such as "Africa Speaks, Africa Answers", "Theme for African Drums" and "Africa Sounds".

3 Ginger filmed a trans-Saharan crossing in 1970 and in Nigeria worked and recorded with Fela Anikulapo Kuti and helped establish the ARC Studio in Lagos.

4 He came to record in Lagos in the early 1970s with his Band On the Run and employed some of Fela Kuti's musicians.

5 I was involved with Sean Barlow's pilot program in Ghana and an early Afropop program on Revofest 1986, a festival of the top band in Ghana held at the Accra Football Stadium that I helped record.

6 I acted as facilitator for the Cato and Bridgeman in 2000 and arranged for them some locations and the musicians Aaron Bebe Sukura and T.O. Jazz.

7 I met him at the EMI studio in 1974 where I was recording. He then went on to tour Nigeria and released a song about his trip called "Have You Heard the News". 
Bob Marley played at Zimbabwe's 1980 independence celebration, and members of the band Police made several visits to Africa.

Fifthly: Reggae facilitated the international interest in African music also through the examples of white reggae bands (like Police) and British two-tone bands of the 1980s. The latter (such as the Beat, Selector, UB40 and the Specials) consisted of white and West Indian musicians and these two-tone bands created simple cross rhythms by combining the percussive reggae upbeat (or "back-beat") with the rock downbeat, or by the white rock guitarists playing on the four beats of the bar, whilst the West Indian guitarist "skanked" on the off-beats. ${ }^{8}$ These two (rock and reggae) opposing rhythmic techniques create a simple cross-rhythm, enhancing the idea of rhythmic space ${ }^{9}$ and opening up the polyrhythmic imagination of Western pop musicians and their dance-fans. ${ }^{10}$ It is no wonder then that Western pop musicians and fans became drawn towards and inspired by the more sophisticated polyrhythms of African dance music, both traditional and popular. ${ }^{11}$ When Bob Marley died in 1981, the manager of his Jamaican-British Island Records company, Chris Blackwell, decided to look for the next super-star from Africa rather than the Caribbean. This leads us to the topic of the role of the independent record labels in the growth of Afro-pop and World Music.

\section{Afro-Pop, World Music and the Role of Independent Labels}

In 1983, Island Records focused its hopes to Nigeria's top juju-music star, Sunny Ade, and started promoting his international touring and releasing of records in Europe. Ade's album "Synchro-System" was juju music influenced by Afro-beat, and it sold well on the international market. Another British independent label, Virgin Records, released another successful Afro-pop album in 1982; this was called "Sounds Afrique" and it consisted of a selection of songs from old master-tapes of the East African version of Congolese soukous music, discovered gathering dust in a Kenyan recording studio by the British musician Ben Mandelsson. From 1983

8 The white guitarist struck the chord with his plectrum or picked emphatically downwards (four time to the four beats of the bar) whilst the West Indian did not strike downwards at all, but rather hit the strings on the upward movement of the plectrum (four times to the four off-beats of the bar). This "skanking" was the basic guitar technique of the early form of reggae known as ska.

9 Two-tone and white reggae music at that time was sometimes called "grill" music or music with holes in it, referring to the rhythmic space the cross rhythms opened up (like the spaces between the cross threads of woven material) for the player, listener and dancer. John Chernoff's book "African Rhythms and African Sensibility", based on his work in Ghana on polyrhythmic wisdom became something of a cult book for artists, such as Brian Eno, Malcolm McClaron, David Byrne, Stewart Copland, Sting and other 1980s' Western pop stars interested in African music.

10 Western music with its single rhythmic orientation and emphasis on the on-beats is sometimes called "one-way" music by Ghanaians.

11 Whereas white reggae and two-tone music involved only two cross-rhythms that were exactly contrary, or out of phase by 180 degrees, the phasing of African music is far more subtle and also often involves more than two cross-rhythms. 
other British independent labels moved into the African popular music business, such as Sterns African Records ${ }^{12}$, Earthworks, Oval, Real World and Globestyle. Unlike the earlier companies operating in Africa, such as Decca, EMI and Phillips/ Polygram, whose African releases were mainly for the internal African market, these independent labels catered for the growing number of white Afro-pop music fans. These British independent labels initially endorsed music from English speaking Africa and later added Francophone African material coming out of independent record companies in France.

By the 1970s France had four million immigrants from its African and Caribbean colonies, and by the late 1970s there were hundreds of African musicians in Paris whose small market was catered for by companies such as Sonodisc, PatheMarconi, Son Afrique and Melodisque. However, things took a quantum leap in 1981 after the multi-cultural approach of the Mitterand government, whose Minister of Culture, Jack Lang, helped fund and organise tours by African bands. As a result, many new French independent Afro-pop labels appeared, such as Syllart, Celluloid, Gefraco and Cobalt, Toure Jim, Wotre Musique, Ngrapy, Mayala and FNAC. Consequently, by the late 1980s, Paris had become an important center for African popular music industry and a "Mecca" for musicians from French-speaking Africa and the Caribbean.

It was only after the pioneering work of these British and French independent African pop labels that the big record companies, such as HMV, EMI and Warner Brothers began to move into African music. For instance, in 1986 the Warner Brothers released Paul Simon's South African inspired "Graceland" album, which sold fourteen million copies and triggered interest in African popular music in the United States. Subsequently, the big distributors began to set up World Music sections in their mega music stores - and as they say, the rest is history.

The word "World Music" was coined by a group of independent recording companies and popular music journalists in London in 1987 to broaden the marketing potential of African popular music or "Afro-pop", as it was originally called. There were two meetings, held in London in 1987 in connection with the launch of the label World Music. The first meeting was called by John Harlow, the editor of the Africa Beat magazine, and it was held at the Café de Musicians in South London. The second was held a little later, in June 1987, at a North London pub called the Empress of Russia, and in this meeting a group of independent record labels decided on the name to be given to the marketing category. I was present at the

12 Sterns had been operating a small shop in London dealing in African records since the 1960s, catering for African students and the small number of Western buyers then interested in ethnic and folkloric music. In 1983 Sterns was bought out by a group of young entrepreneurs who decided to expand from retailing into music production. 
first meeting and, with Charles Eassmon ${ }^{13}$, we opposed the change of name from Afro-Pop to World Music as we thought it would obscure the fact that African dance music had become mainstream music rather than being ethnic music. We also believed that the new title would undermine the fact African popular music was the very engine and the battering ram that had created this new slot in the international record markets. We were opposed, however, and told that the name "Afro" was outmoded and a new word was needed.

Initially, some of my reservations about the new title were confirmed. For instance, some African run discos in the UK were suddenly considered too narrow in their musical scope by the World Music audience. Furthermore, the pioneering layer of the Afro-pop writers and radio and newspaper journalists were quickly pushed aside by armchair experts and reggae journalists, who suddenly posed as African experts. Nevertheless and by whatever name, the fact is that African popular music has created a new marketing slot in the global music market and even today a significant portion of all World Music releases are of African music. Despite the change of name from Afro-pop to World Music this new slot in the international record market has benefited Africa and African musicians in several ways.

\section{World Music: Positive Consequences for Africa and African Musicians}

\section{Growth of International Sales and Royalties of African Music}

Up to the 1980 s, with a few exceptions ${ }^{14}$, international sales of African music were generally quite small and limited to small shops catering for African students, and those interested in ethnic music. From the almost minimal international sales from the 1950 s to the 1970s, the market expanded into a multi-million dollar one between the 1980s and 2000. Based on the figures in the late 1990s, I have estimated that the African component of World Music is around 25 percent and that the total revenue from the sales and the royalties of this African segment of World Music sales and royalties is almost 1.5 billion dollars a year (see appendix A).

\footnotetext{
13 A Ghanaian with the then Sterns African Records and later Director of the Afro-Caribbean Music circuit linked to the British Arts council.

14 Some exceptions are as follows: first, during the 1950s, the South African songs Penny Whistle, Tom Hark, and Wimoweh or "The Lion Sleeps", popularised by Pete Seeger; secondly, the music of South African exiles, such as Abdullah Ibrahim (Dollar Brand), Hugh Masekela and Miriam Makeba (Malaika and the Click Song) during the 1960s; thirdly, the Soul Makossa disco hit in the United States by the Cameroonian Manu Dibango, and the Afro-rock hits of the London-based Ghanaian band Osibisa during the early 1970 s.
} 


\section{World Bank Interest in Assisting African Music Industries}

Largely due to the growth of the World Music market, the World Bank has recognized the economic potential of the local music industries for African countries. In June, 2000, a one-day workshop was put together at the World Bank headquarters in Washington DC to discuss ways of assisting the music industry of sixAfrican countries (South Africa, Zimbabwe, Ghana, Nigeria, Senegal and Mali). Besides the World Bank, there were representatives from EMI, IBM, the World Intellectual Property Organisation (WIPO), and a music expert and economists. ${ }^{15}$ Areas discussed were soft micro-credit loans for the musicians, bands and clubs and for the setting up of digital studio-cum-websites in Africa for distributing locally produced music (by MP3, Napster, etc). The other issues discussed were the possibilities of direct grants for reviewing the copyright legislation, upgrading and making transparent African royalty collecting organizations, supporting music unions, providing free legal aid for poor musicians and for providing music educational equipment.

In the case of Ghana I especially argued for the World Bank to support the live music industry in Ghana, partially collapsed during the late 1970s and 1980s, but vital for both the local tourist industry and for expanding the Ghanaian content of the World Music sales. However, because Ghana did not at the time have any clauses in its dealing with World Bank concerning the commercial music and entertainment sector, Senegal (which already had such clauses) became the first recipient of this initiative, receiving just over five million dollars in support of its music sector.

\section{Double Market for African Music}

Besides the internal African market there is now an international market deriving from the World Music sales and royalties. This double market includes Africans, on the one hand, and the World Music fans, on the other. Of the Africans, the young especially turn towards hi-tech music, whereas the World Music fans want what they consider "authentic" African music. The reason for this distinction is that Western World Music fans have become over-saturated with hi-tech music and are looking for "back-to-roots", "live" and "unplugged" music. On the other end, African popular music fans are rather fascinated with artificial hi-tech sounds, which to them symbolically represent modernity and which they hope will help them leapfrog into the $21^{\text {st }}$ century. This difference between the internal modernistic African one and the romanticized World Music marketing profile has been commented on by some writers. For instance, the British music magazine Songlines (2005) released an issue, called the Great Debate, in which the British-based Nigerian

15 I was invited by World Bank because they knew of my book (Collins 1992). 
commentator Bisi Adepegba ${ }^{16}$ accused World Music fans who dislike computerized African music and search for "authenticity" for being musical neo-colonialists and for patronizing Africans.

I, for one who lives in Africa, take a less polarized view and treat the two psychological profiles of African music buyers (that is, the internal African and the international World Music) as a positive potential for African musicians, for the situation allows them to tap into a double market that puts money into their pockets. So this is not a question of political correctness but of livelihoods and survival of African artists. Some African musicians are already tapping into this double market. For instance, the famous Senegalese singer Youssou N'Dour often makes two mixes of his songs in his studio in Dakar. For the local market with its hitech taste he uses drum machines and synthesizers, whereas for the World Music market he uses live drums and a large horn section. Far from being a touristy "hotel singer", as Adepegba claims, Youssou N'Dour is rather a sophisticated artist who understands the various psychological profiles of his fans, and is therefore able to cater for the different audiences. There are several positive impacts of the World Music industry specifically for Ghana that I will explore next.

\section{Ghana and World Music}

\section{World Music as a Boost for the Tourist Industry}

Twenty years ago tourism in Ghana was literally at a standstill, largely due to political instability, the problems of artificial exchange rates and the resulting black market, as well as shortages of even the basic commodities. However, particularly after the IMF initiated Structural Adjustment Policy of the late 1980s, tourism has dramatically increased in Ghana; between 1992 and 2002, the number of tourists entering the country each year doubled. In 2003, 550.0000 tourists visited Ghana, and in 2004, 650.000 came. In 2000 foreign tourism generated US\$ 350 million for Ghana, and in 2004 , US $\$ 800$ million, making tourism the third largest foreignexchange earner for the country - after gold and timber. By 2007 tourism was expected to attract one million visitors a year to Ghana, generate US $\$ 1.5$ billion in foreign exchange, and create 300.000 local jobs, thus making tourism the largest employer in formal sector after agriculture, trade and industry. ${ }^{17}$

It has been estimated that ten percent of the foreign exchange that international tourists spend is on recreation and entertainment. Part of the growing sector of

$16 \mathrm{He}$ also says that World Music stars like Salif Keita and Youssou N'Dour (e.g., his recent collaborative Egypt album) are merely "hotel singers" whilst Angelique Kidzo (Benin) and Rokia Traore (Mali) are hardly known in their own countries

17 Speech by the Minister of Tourism, Mr. Jake Obetsebi-Lamptey, in October 2005. 
the Ghanaian tourism comes from the impact of the World Music tourists who come to Ghana for its highlife and popular night-club music, and its traditional folkloric groups performing at local festivals and ceremonies, as well as hotels and beach resorts. Some of these World Music tourists come to study, artistically or academically, local music and dance.

World Music fans and foreign tourists in general enjoy live performances of bands with a strong indigenous African flavor. This is why the current Ministry of Tourism has put its weight behind the moves to facilitate increase in the number of live bands and night-clubs that cater for them. One such move supported by the Ministry was the government decision in early 2004 to reduce the high import duties on musical instruments, which has been crippling the local live music industry over the last twenty years.

\section{Paul Simon and the Creation of the Ghana Folklore Board}

In October 1990 Paul Simon followed up his 1986 South African-oriented "Graceland" album success with another album "The Rhythm of the Saints" on the WEA Warner Brothers label. For some of the songs he collaborated with the Ghanaian bass player Kofi Electric and the Cameroonian guitarist Vincent Nguni. A song called "Spirit Voices" was partly based on the melody and rhythm of the old Ghanaian highlife song "Yaa Amponsah", the name of a beautiful lady dancer of the 1920s. As for the royalty payments, Paul Simon contacted the Ghana Embassy in New York that advised him to send the US\$16.000 of royalties collected by then (now the royalties have amounted to US\$ 80.000) to the Ghana Copyright Administration, under Ghana's equivalent of a cultural ministry, the National Commission on Culture (N.C.C.)

Under its then Director, Dr. Mohammed Ben Abdullah, the N.C.C. set up a committee to look at the exact origin of the song "Yaa Amponsah", which was first recorded by Kwame Asare (Jacob Sam) and the Kumasi Trio in 1928 for the British Zonophone Company (later incorporated into EMI). Indeed, Paul Simon had been advised by Ghanaians in the United States that the "Yaa Amponsah" was Kwame Asare's composition and therefore Simon had ear-marked the sixteen thousand dollars for Asare via the Copyright Administration. For several reasons ${ }^{18}$ the N.C.C. eventually deemed the "Yaa Amponsah" song an anonymous folkloric work. For that reason, in 1991 Paul Simon's money was used to establish the National Folklore

18 The song had been around for at least ten years before the 1928 recording. Other names have been put forward as its author. According to A. T .A. Ofori and Daniel H. Acquah $(1929,11)$, the late Beattie Casely-Hayford, an old lady taught the melody to Kwapong. Also the Achimota schoolteacher W. E .Ward notated three versions of Yaa Amponsah (1927, 199-223). Further complicating the picture is that Kwame Asare's guitar two-finger picking technique was taught him by a Liberian Kru (Collins, 1996, 1) and the Yaa Amponsah rift is structurally related to an old Liberian guitar style known as Mainline. 
Board of Trustees that (then) had close ties with the Ghana government's Copyright Administration. The Folklore Board was charged with making an inventory of all of Ghana's tangible and intangible folkloric works (not just music) and to monitor their commercial use by foreign artists and companies from the industrial nations, who would in the future have to seek permission from and pay a fee to the Board. ${ }^{19}$

Although Paul Simon's money was put to good use there was one unforeseen negative result. The copyright lawyers on the Folklore Board wanted to extend this folkloric license from foreigners to Ghanaians. Even though this was vigorously opposed by some of the performing artists on the Board (the musician Koo Nimo, the poet Kofi Anyidoho and me) and members of the wider Ghanaian artistic community, the folkloric license clause for Ghanaians was incorporated into the new copyright bill and the issue has not been fully resolved to this date.

\section{Increasing Number of Foreign Musicians Visiting Ghana and Collaborating with Ghanaians}

From the late 1970s to mid-1980s there were few visits by foreign musicians to Ghana due to the economic and political problems of the time. There were a couple of exceptions, however. In 1980 Brian Eno visited and helped a local producer, Faisal Helwani to record the Edikanfo Afro-rock band. In the same year Mick Fleetwood (the English drummer of Fleetwood Mac) came with a 24-track studio, and in collaboration with the Musicians Union of Ghana and the Ghana Arts Council made a film called "The Visitor" that involved several Ghanaian artists and bands. During the 1980s there were also some notable collaborations between Ghanaian and Western World Music stars, working outside of Ghana. In addition to Paul Simon, there was Nana Danso Abiam and his Pan African Orchestra that worked in the UK with the ex-Genesis rock musician Peter Gabriel, performed at the WOMAD World Music festival and released the 1988 World Music chart hit "Opus One"on Gabriel's Real World record label.

By the early 1990s, the effects of the liberalisation of the Ghanaian economy led to increasing numbers of foreign visitors coming to Ghana - including musicians. For example, in 1991 the first of a series of Panafest or Pan African Festivals was initiated by the government. Over the years Panafest brought in many thousands of African-American tourists - including musicians such as Steve Wonder, Public Enemy, Dionne Warwick and Isaac Hayes.

19 A later similar source of foreign revenue for the Folklore Board was several thousand dollars from the Japanese Victor Company for its use of some Ghanaian traditional material on its 1996 commercial JVC/Smithsonian Folkways Video "Anthology of African Music and Dance". 
From the USA and Europe came the jazz musicians Randy Weston and Max Roach (the latter visiting the Ghanaian master drummer Kofi Ghanaba/ Guy Warren) as well as the German percussionist Robin Schulkowsky, who recorded with Kofi Ghanaba. From the United States came Caron Wheeler of the Soul 2 Soul band, Jermain Jackson and Shaggy. In 1999, Jamie Cato and Duncan Bridgeman of the British pop band Faithless came and worked with Ghanaians, as part of their intercontinental musical Odyssey, which resulted in a DVD in 2003, called One Giant Leap that wan two Grammy awards. Among the more recent visitors is the black British sax player Courtney Pine from the UK. Many artists have also come to Ghana since the late 1980s from the Caribbean, such as Misty and Roots, Musical Youth, Greg Isaacs, Kassav, Culture and Rita and Ziggi Marley. Rita Marley has settled in Ghana and built a recording studio in the Aburi Hills near Accra.

\section{Revenues for Touring Ghanaian Bands and Ghanaians Resident Abroad}

Besides foreign bands coming to Ghana, since mid-1980s and with the rise in interest of World Music an increasing number of Ghanaian based artists and bands have toured in the US, Europe and Japan. ${ }^{20}$ Furthermore, many Ghanaian performing artists have been or remain resident abroad. Some are members (or leaders) of African traditional and popular music bands, whilst others are solo artists, session musicians, members of cross-over World Music bands, or teach African drumming and dancing in schools and colleges. ${ }^{21}$

\footnotetext{
20 Mac Tonto's Kete Warrriors, Guy Warren (Kofi Ghanaba), the Pan African Orchestra, Kwabena Nyama, Koo Nimo, Local Dimension, Rocky Dawuni, the Western Diamonds, City Boys, Amkeyke Dede, Kojo Antwi, Blay Ambulley, Pat Thomas, Papa Yankson, Jewel Ackah, Captain Yaba George Darku, Daddy Lumba, C.K. Mann, A.B Crentsil, African Brothers, Kente, Kakraba Lob,. Osei Korankye, Bukom Ensemble, Bernard Woma, the Dzinpa Cultural Group, Sogo, Dzembii, African Showboys, Nii Adu Ofoliquaye's Bukom Ensemble, Francis Nii Yartey.
}

21 The following is a list of some of the musicians who by the mid-1980s and 90s had permanently settled abroad or had spent extensive periods abroad. USA: Obo Addy, Yacub Addy (Odadaa Band), Amartey Hedzolleh, Okyerema Asante (with Paul Simon and Mick Fleetwood), Jerry Hansen (Ramblers), master percussionists Kobla and C.K. Ladzekpo, Kwarshi Amuvor, C.K.Ganyoh, Gideon Foli, Godwin Agbeli, Kwasi Baidoo, Adjei Abankwah. Canada: Pat Thomas, Alfred Schall (Wanaa Wazuri Band), Nana Yaw Boakye (Nakupenda), Bishop Okele (Officials). Denmark: Afro Moses (O'Jah), Henry Soloman (Zebra). UK: Alfred Bannerman, Nana Tsiboe, Atongo Zimba, George Dzikunu, Ray Allen, George Lee (now in South Africa), the late Jon Kay, Mike Osapanyin (Kabala), Kwabena Oduro Kwarteng (Highlife Internationals), Kofi Edu, Ben Brako, Sol Amarfio and Teddy Osei (Osibisa), Lord Eric, Ben Baddo, Nii Abbey Mensah's Abladie Ga Cultural Group.. Holland: Kofi Ayivor, Sloopy Mike Gyamfi (Sankofa), Charles Tetteh. Australia: Little Noah (Kotoka Mma), Eddie Quansah (the Black Trumpet), Aweke Glyman, Kojo Ashakan. France: B.B. Brew, the late Stanley Todd. Austria: master drummer Mustpapha Tettey Addy. Germany: highlife musicians Daddy Lumba, George Darko, Rex Gyamfi, Bob Fiscian, Allan Cosmos Adu, Charles Amoah, McGod, Lee Duodu, Bob Pinodo and the Adesa Cultural Group . 


\section{World Music Tourists Enhancing Traditional Ghanaian Music}

There has happened what can be called a "folkorisation" of Ghanaian traditional music and dance, which means taking indigenous performance out of its ethnic and communal context and putting it on stage, into class-rooms or into recording studios. This "folkorisation" process really took off already after the independence of Ghana in 1957 when the leader of the country, Kwame Nkrumah initiated national festivals, established an Arts Council and Ghana Dance Ensemble and began the teaching of traditional African music in schools and universities (such as the Institute of African Studies and School of Performing Arts).

However, "folklorisation" has now expanded from its role in serving government's national cultural policy to being part of private commercial and educational initiatives. This began in the late 1980s with the boom in Ghanaian tourism (including World Music tourism) when many folkloric "cultural" and "neo-traditional"22 groups were encouraged to perform at beach-clubs and hotels to the interest of the foreign visitors. Furthermore, many private and non-governmental (NGO) cultural centers were established to teach traditional music and dance, several of them at beach resorts. ${ }^{23}$ The first one of such centers was the African Academy of Music and Arts (AMAA), set up at the fishing village of Kokorobite in the late 1980s by the masterdrummer Mustapha Tettey Addy. There are also local cultural groups that double up as teaching units for foreign visitors from time to time. ${ }^{24}$ Additionally, since the 1990s, hundreds of foreign drum and dance students attend the University of Ghana School of Performing Arts at Legon each year.

Many think that the tourist industry can only have a bad effect on traditional culture, making it less "authentic" by watering it down and pre-packaging it. However, there is a clear positive side to tourism in this case, since the tourist and World Music interests in traditional African music have financially encouraged

22 "Cultural" is a term often used in Ghana for "traditional" ethnic based performance. "Neotraditional" groups are ones that use local instruments but not necessarily from the same ethnic or even African community, for instance, pan-African type of music ensembles.

23 Some other examples of the 16 current drum-dance private teaching centers are the Dagbe Drum School at Kopeyi in the Volta Region (established by the late Godwin Agbele), Koo Nimo's music school in Kumasi, Kasapaa at Nyanyano (German/Ghanaian), the Kukye-Kukye Bamboo Orchestra and Centre at Masomogor village near Kakum Nature Reservation, the AGORO informal education music through NGO at Cape Coast (Danish/Ghanaian), Akoma Village in Accra, Aklowa at Kokrobite, the Dagara Music and Arts Centre at Medie (established by Bernard Woma) and Afrihi in Accra.

24 Some of the 21 of the joint perfomance/ teaching groups that I know of are the following: The Suade Cultural Group, Kusum Gboo, Kake Dance Ensemble, Nananom Dance Ensemble, Bomsako Cult Group, Nii Tettey Tetteh's Kakatsitsi (called later Kusun Ensemble), Dzembii, Hewale Sounds, Sensational Wulomei, Afro Aburukusu Orchestra, Nii Amah Akomfrah's Afrika Obonu, Johnson Keme's Brotherhood Foundation Cult Group, the Odehe Dance company, Dzinpa, Sogo Atmudan Group, the Royal Obonu Drummers (Mustapha Tettey Addy), Kakraba Lobi (gyil xylophone), the Pan African Orchestra. 
young people to learn the performance skills of their elders, which otherwise might have been lost.

Many of the cultural and folkloric groups that perform at hotels, beach resorts, cultural centres and educational institutes do recordings. The 1988 "Opus One" World Music hit was already mentioned. The famous Ga drummer Mustapha Tettey Addy has released a string of records and CDs on the German Weltwunder label. Many other folkloric and neo-traditional groups and artists have been releasing materials in the last ten years, and here I will just mention a few. There is the university based neo-traditional group Hewale ${ }^{25}$, which combines local instruments from the different regions of Ghana and which has made two CDs since 2000. There have been cassette releases of Akan Nwonkoro music by groups such as Onyame Krabae. ${ }^{26}$ Another Akan style is represented by Osei Kwame Korankye, who has been reviving, teaching and recording the almost defunct seprewa harp-lute at the university of Ghana. From the Ga area comes the Sensational Wulomei, whose records combine local percussion with the highlife guitar, and Ebaahi Soundz, who released their fifth album "Naa Daniowie" in 2005. ${ }^{27}$ From upper eastern Ghana are the African Showboys, a group of brothers who have been performing Frafra music onstage since the 1980s and released a CD in the US. From the Upper West Region of Ghana comes the internationally recognised performer and teacher of the Dagari "gyil" pentatonic wooden xylophone, Kakraba Lobi, who has released two CDs in the US since 2000. Finally there has been a resurgence in recording sales of folk guitarists like Koo Nimo, Kwabena Nyama, Kwaa Mensah and others, who have been releasing the old palmwine version of highlife in recent years (see Appendix B and C).

\section{Commercial Music has Become Part of the Government's Official Policy}

Although Ghana's first leader, Kwame Nkrumah, included the commercial music and entertainment sector in his policy, as he recognized the role of popular performers in the independence struggle, ${ }^{28}$ subsequent governments took little official interest in this sector, despite of the rise of tourism and the World Music phenomenon from the mid- to late 1980 s.

25 Run by Dela Botri and now based at the W.E.B. DuBois Centre in Accra.

26 Pioneers of this music that is largely a female genre, are the Manhyia Tete Nwonkoro group of Kumasi led by the late Madam Afua Abasa.

27 This group was initially a youth group known as Ebaahi Gbiko, which worked with the English rock drummer Mick Fleetwood in 1980 (on his film The Visitor) and won the third Children's Folk Music Contest in 1983.

$28 \mathrm{He}$ helped to create many state highlife bands and concert parties, encouraged the formation of two music unions (affiliated to the Trade Union Congress) and turned the colonial film unit into a commercial film and audio recording studio (Ghana Film Corporation). 
However, under the Kuffour government there was a change which was partly a result of the 2000 decision by the World Bank to give grants and soft loans to the African music industry. In 2004, the import duties on musical equipment were reduced. In 2005, the music industry sector was added to the Ghana Poverty Reduction Strategy. ${ }^{29}$ The Ministry overseeing this sector is the Ministry of Tourism. In sum, then, I would emphasize the positive impacts and potentials that the World Music phenomenon has brought for African and Ghanaian music and music industry. Some of these impacts are direct, others more indirect, but the positive result has been the enhancement in opportunities of African music and musicians within and outside the continent.

29 This was done after a team comprising Professors Komla Amoaku and Korkor Amarteifio of the Institute of Music and Development and Professor Collins came together to conceptualize and organize a workshop on the theme "Mainstreaming Music in Ghana's Poverty Reduction Strategy Program". They first met and discussed the matter with Dr. William Ahadzi of the University of Ghana and a member of the GPRS team. This was followed by a workshop held at GIMPA in Accra and the Chances Hotel on April, 2005. Those invited included thirty musicians, music producers, journalists, artistic managers, and representatives of music unions, the legal profession, academics, the government GPRS review team and development partners. A committee was set up at the workshop and the recommendations were submitted to the GPRS review team for inclusion in the GPRS. 


\section{Appendix A}

The figures were compiled for a World Bank report. In my original report for the World Bank my estimate was much lower (see: <<siteresources.worldbank.org/ INTCEERD/Resources/CWI_music_industry_in_Africa_synopsis.pdf $>$ _). I arrived at the $\$ 1.5$ billion figure shortly afterwards and presented it in a paper entitled "Making Ghanaian Music Exportable", organized by the Ghana Music Awards and held at the National Theatre in Accra on 6 April, 2001. This figure is a guestimate I arrived at in 2000 with the assistance of some of my foreign students whom I asked to calculate the portion of African music on World Music shelves of music shops in the US and UK. For instance one quarter of the US Tower Records' World Music catalogue of July 2000 was of black sub-Saharan African music releases. The calculations for the sum:

Music Sales and Royalties at the End of the 1990s:

\section{1) Music sales (US\$)}

Total global music sales $\quad=36,000,000,000$ (thirty-six billion)

Total global "World Music" sales in $1999=5,000,000,000$ (five billion)

African component of the above $(1 / 4)=1,250,000,000$ (one and a quarter billion)

\section{2) Royalties (US\$)}

Total Global royalties in $1997=6,300,000,000$ (six point three billion)

World Music royalties ( $14 \%$ of the above) $=880,000,000$ (approx.)

African component of this $(1 / 4) \quad=220,000,000$

Total music sales and royalties (US $\$$ ) $=1,470,000,000$

$(1,250,000,000+220,000,000)$ 


\section{Appendix B}

Some Ghanaian World Music releases since the 1990s (traditional material is listed in appendix B):

Although Ghanaian music does not have as high a profile on the World Music market as the music of Mali, Senegal, Nigeria and South Africa, it is still considerable. And since the success of the Pan African Orchestra "Opus One" release in 1988 (Realworld/ WOMAD) a considerable amount of Ghanaian material has found its way onto the World Music shelves in American, Europe and Japan.

E.T. Mensah: Day by Day \& All for You/ King Bruce and the Black Beats/ Guy Warren Ghanaba (RetroAfric, UK). Rough Guide to Highlife (Rough Guide Music, UK). Afro-Rock (Kona Records UK). Music in Ghana (Pamap Germany). Ghana Soundz (Soundway UK). Guitar and Gun (Stern's/ Earthworks, UK). Highlife All Stars (Network Germany). Vintage Palmwine/ Kofi Ayivor: Rhythmology (Otrabanda Records, Holland). Electric Highlife (Naxos, USA/ Hong Kong). Popular Music Ghana 1931-57 (Disques Arion Paris). Okyerema Asante and the Uhuru Band: Crabs in a Bucket (Asante/ Oyigbo label, USA). Rocky Dawuni: Crusade \& Awakening (Aquarian Records, Ghana/ USA). Afro Moses: Makoloa \& O'Jah (Riddimtrax Records/ GMF Label Denmark). Sloopy Mike Gyamfi: Telephone Nkomo \& Asem Kakra (Holland). Nat Brew: Wogbe (Amanazeba Productions). The Shrine: Afrobeat (Ocho UK). The Highlife All Stars (Network Germany). Eric Egyeman: Ghana Gold (Music and Words, Holland). Smilin Osei: Alarm Blo (Dakar Sounds Holland). Nana Tsiboe and the Supa Hilife Band: Ahom \& Asem Ni (Tuntumi, UK). Amartey Hedzolleh (Millenium Anthem Productions, USA). One Giant Leap (Palm Pictures, UK). Alex Konadu: Greatest Classic (Sam Records). A. B. Crentsil: Menba Bio Nakasi (Afro Records 2005). Daddy Lumba: Poison (Lumba Productions). Best of Highlife (Joe Etti Productions/ Melodie Distribution). Jewel Ackah: Butu Sela (Katanga Productions, US). Nana Acheampoing: Greatest Hits. West African (Nigerian) Highlife Bands: Salute to the Pioneers (Spirit Records USA). Ramblers:Timbuctu (UK). Sweet Talks: Popular African Music Compilation (Gunter Gretzt Productions Frankfurt Germany). King Onyina: Popular African Music Compilation (Gunter Gretzt Productions). Nana Tuffour: Genesis (Shuffle Music, Germany). Pat Thomas Retrospect: Sika Ye Mogya (Tropic Vibe USA). Terry Bonchaka: Ghana Ladies(Tropic vibe, USA). Best of Lee Duodu and Cantata (Nakasi Record Productions). African Brothers Greatest Hits (USA). Kofi B: Aserewa (Slip Music/Despite Music/ Owusek Productions, New York). Dada K.D.: Mehura (Tropic Vibe USA). Kofi Bentsil ans the Western Diamonds Band: Passanga Highlife Boogie (Sterns, UK). Nana Tuffour: Sankofa (G Money Productions, USA). Early Guitar Music from West Africa 1927-9 (Heritage Records, UK). Eric Agyeman: Highlife Safari (Sterns). Kwadwo Donkor Presents Uhuru: Sounds of Africa (Agoro Records, Ghana). Lord Kenya: Sika Mpo Nfa Neho (Mount Kenya Productions). Blay Ambullay: Son of Africa (Simigwa Records US). Kari Bannerman: Ghana Gone Jazz (Seprewa Records, UK) Soul and Spirit (Bibini Music, Ghana). 


\section{Appendix C}

Some neo-traditional/ folkloric releases since the 1990s:

1. George Aingo: "The Roots of Highlife". Heritage, UK.

2. "The Kumasi Trio" 1928 folk guitar. Heritage, UK.

3. Obo Addy releases include "Afieye Okropong", "Wonche Bi”. Akula Records, USA.

4. Adesa Cultural Group "Akoma”. Peter Weigelt's Grenzland Studio Germany, 2004.

5. Mac Tontoh and the Kete Warriors "Nana Eba". Amamanas Productions, UK.

6. Kakraba Lobi xylophone (gyil) "Song of Nhira", Manadara Music, USA, 2001.

7. S.K. Kabraba "Gandayina".

8. Hewale "Bayuke" and "Trema" (Cowry Shells), Peogal and Co, Ghana.

9. Osei Korankye "Me Eye Wo Ase" CD, 2001.

10. African Showboys "Brother Bold". USA, 2005.

11. Sogo Cultural Group "Uno Went Ne" CD, 2004.

12. Kusun Ensemble "Nokoko" (Something-Something). Recorded/ distributed by Pidgin Music 2004/5.

13. Onyame Krabae Nwomkro (i.e. Nnwonkro) Group cassette Addai Cutless, released circa 2000.

14. Vintage Palmwine, Holland: Three legends of old Ghanaian acoustic "palmwine" highlife (Kwaa Mensah, Koo Nimo and T.O. "Jazz" Ampoumah. Otrabanda, Holland, 2003.

15. Koo Nimo "Tete Wobi Ka". Human Songs Records, US, 2000.

16. Koo Nimo "Osabarima". Adasa label, re-issued by Sterns 1990.

17. Kwabena Nyama: "Sunday Monday". Arion Disques, 2000.

18. Kwabena Nyama: "Ghana Palm Wine Music". Buda Music, Paris.

19. Atongo Zimba, traditional Ghanaian lute player: "Savannah Breeze". Hippo Records, Holland, 2004.

20. Mustapha Tettey Addy: "Secret Rhythm", "Come \& Drum", "Smart Boys". Weltwunder, Germany.

21. Kakraba Lobi: "Song of Legaa" and "Song of Nhira". Manadara/ Kalaeidoscope Music USA, 2001 and 2004.

22. Captain Yaba: "Yaba Funk" RetroAfric, UK re-release of a 1996 album of traditional Ghanaian lute with Ninkribi band called "Tinanure", recorded at the ARC Studios in Tema, Ghana.

23. Bewaare - "They are Coming: Dagaare Songs and Dances from Nandom, Ghana" and "In the Time of My Fourth Great-Grandfather: Western Sisaala music from Lambussie, Ghana". Both on Pan Label, 1994

24. "Akom: The Art of Spirit Possession". Akan religious drum music, Village Pulse.

25. Aja Addy: "Tsui Anaa Live Refreshment", Weltwunder.

26. The Yaw Dwene and Yaa Adusa Pokuaa Nnwonkro Group "The Legends".

27. The Ehekye Collective "Womba", WOM001, UK, 2004.

28. Sensational Wulomei "Sani Masye Eko". Tropic Vibe, US, 2001. 


\section{References}

Adepegba, Bisi 2005. Songlines, March/April no.

Chernoff, John 1979. African Rhythm and African Sensibility. Chicago: Chicago University Press.

Collins, John 1992. West African Pop Roots. Philadelphia: Temple University Press.

1996. Highlife Time. Philadelphia: Temple University Press.

Ofori A.T.A. \& Daniel H. Acquah 1929. Zonophone Catalogue of West African Native Artists, record number EZ 74, 11.

World Bank workshop on music industry in Africa: <<siteresources.worldbank.org/INTCEERD/ Resources/CWI_music_industry_in_Africa_synopsis.pdf $\gg>$. 